\title{
A COMPARISON OF GLOBAL FINANCIAL MARKET RECOVERY AFTER THE 2008 GLOBAL FINANCIAL CRISIS
}

Prof. Jennifer Foo

Stetson University

Department of Finance

School of Business Administration

421 N. Woodland Blvd, Deland, FL USA 32723

e-mail:jfoo@stetson.edu

Prof. Dorota Witkowska

University of Lodz

Department of Finance and Strategical Management

Matejki 22/26 65, 90-237 Łódź, Poland

e-mail:dorota.witkowska@uni.lodz.pl

Received 26 September 2016, Accepted 26 September 2016

\begin{abstract}
The Financial Crisis of 2007-2009 plunged countries into a Great Recession and focused the world's attention on the global stock markets. The global contagion has a major impact on global stock markets, with the U.S. DJIA falling to 6,547.05 on March 9, 2009 from a high of 14,164.53 on October 9, 2007, with a loss of more than $54 \%$. Other stock markets also had a precipitous drop during the financial crisis. However, some equity markets have recovered while others have not. This paper looks at how global markets compared in their recovery. This paper also investigates the advanced countries' recovery relative to the emerging and developing countries in the aftermath of the financial crisis and their ability to climb back to the pre-financial crisis levels. Analysis is provided for 31 stock indexes from January 2005 to March 2013. In 2013 the majority of analysed stock markets recovered from the crises regardless of if they belong to the group of developed or emerging markets.
\end{abstract}

Keywords: Financial Crisis, Stock Markets, Global Markets

JEL classification: GO1, G15, F01 


\section{Introduction}

Global financial markets are becoming more and more globalized and integrated with the advancement of sophisticated technology and the standardization of global financial products. This interconnection has resulted in greater speed and amplification in the volatility of global contagion from a particular national financial crisis: Thailand and the Asian Crisis (1997), the Argentine Crisis (2001). This interconnection is more pronounced today between advanced and emerging countries with the United States Subprime Mortgage Financial Crisis of 2008 (FC08). The FC08 has shown that a localized housing sector failure in one country may have global contagion on the rest of the world through the interconnection of sophisticated financial vehicles between banks and non-banks. The global economy went through a period of unprecedented financial instability in 2008-2009, accompanied by the worst global economic downturn and collapse in trade in many decades (International Monetary Fund, 2010a).

A global financial crisis is reflected in global stock markets correlations and crashes, not only among developed countries but with emerging countries as well. A study of the recent 2008 global Financial Crisis and the global stock market recovery will shed light on the differences in recovery between developed and emerging economies. The present study aims to look at a comparison of stock market returns and the degree of recovery in global stock markets. In our analysis, we apply statistical inference to verify the hypotheses that the recovery of stock markets at selected diverse stock exchanges around the world are disproportionate. The degree of severity and volatility of the stock markets and its recovery would help to understand the impact and consequences of a financial crisis in different markets.

\section{Literature Review}

There exists extensive literature on the causes and remedies of global financial crises. The research really took off after the Asian Financial Crisis (Goldstein, 1998; Radelet, Sachs, 1999; Sheng, Tu, 2000), followed by later studies on the Russian Crisis (Dungey et al., 2002; Sojli 2007) and the Argentine Crisis (Boschi, 2005; Goldberg et al., 2000), to name a few. Despite the numerous studies and policy recommendations, the lessons have not been learned and the prevention of the reoccurrence of global financial crises has not happened. The most recent global U.S. Subprime Mortgage Financial Crisis of 2008 (FC08) similarly engenders a plethora of research on the causes and consequences with policy recommendations.

The literature on the FC08 can be divided into two basic groups; those that focus on the causes, consequences and reforms, and those that focus on the stock markets crash, returns 
and volatility. The causes of the FC08 have been attributed primarily to the excessively loose U.S. monetary policy of 2002-2004 and an extended period of abnormally low interest rates, excessive borrowing, lending and investment together with lax regulatory oversight and imprudent lending practices (Bordo, 2008; Arner, 2009; Mohan, 2009).

Many studies have shown the growing degree of stock market volatility and spillovers from global financial integration and interdependence (Longin, Solnik, 1995; Nguyen, 2005; Edwards, Susmel, 2001; Forbes, Rigobon, 2002; Phylaktis, Ravazzolo, 2002). This group of literature looks at the global impact of stock market crashes which is a secondary reaction to financial crises and deteriorating confidence in economic performance.

Chang (2012) finds that in comparing the volatility of the Taiwan stock market (TAIEX) to the USA (S\&P500) and Europe (EURO STOXX 50) before and after the FC08 crisis, the Taiwan stock market shows greater volatility for a longer period and that negative information has a greater impact on market prices in Europe and the USA. Prior to the crisis, stock markets like the SEMDEX (Mauritius) that were previously not sensitive to external shocks felt the effects of the FC08 contagion and portfolio diversification for global investors is only beneficial pre-crisis and not post-crisis (Ramlall, 2009). This sentiment of "no place to hide" for global investing when a financial crisis hits and the need to rethink the equity risk and global diversification has strong implications for modifying investing behaviour and strategies (Bartram, Bodnar, 2009). In a further study using GARCH modelling, Ramlall (2010) finds that volatility clustering in the NASDAQ, DJIA, and Hang Seng (Hong Kong) stock indexes is more pronounced as a result of the FC08 credit crunch while leverage effects have a greater impact on the emerging markets for JSE (South Africa) and SSEC (China) indexes post crisis. He concludes that the subprime credit crunch heightened not only the volatility clustering but also increased the leverage effects for global stock markets, especially for emerging markets. Kenc and Dibooglu (2010) conclude that the stock market volatility from the FC08 crisis is unprecedented; however, their measure of the unit price of risk based on the long-term daily data on the Dow Jones Industrial Average (DJIA) is not much different from the Great Depression and the technology bubble. Emerging markets are not immune to the transmission of stock market volatility from the FC08 crisis and their policies to insulate themselves proved inadequate (Dooley, Hutchson, 2009). In a recent study, Rejeb (2013) shows that stock market volatility and contagion can be transmitted across borders between emerging markets and between emerging and developed markets during a financial crisis period like the FC08 crisis.

The crash of 2008 was unprecedented in that the equity reduction and loss in wealth were felt globally in every major sector and industry. Stock markets react to financial crashes by 
fleeing perceived risky and volatile assets to safe havens of Treasury bonds. Although major assets classes declined sharply, emerging market stocks declined by more than $50 \%$ and U.S. stocks dropped by $37 \%$ in 2008 . Financial assets like treasury securities and other safer assets gained as investors flee the volatility (Table 1). In the wake of FC08, global diversification as a basic strategy of portfolio diversification in this case did not diversify away risk whether it be U.S., emerging markets or foreign stocks. Neither were precious metals and municipal bonds safe.

Table 1. Total returns from different assets in 2008 (percentage change year to year)

\begin{tabular}{|lc|lc|}
\hline \multicolumn{2}{|c|}{ Asset declines } & \multicolumn{2}{c|}{ Asset Gains } \\
\hline Emerging markets stocks & -53.5 & Treasury bills & 1.5 \\
\hline Foreign stocks & -43.1 & Money-market funds & 2.0 \\
\hline U.S. stocks & -37.0 & U.S. high-quality corporate bonds & 6.6 \\
\hline Precious metals & -29.9 & European bonds & 7.2 \\
\hline High-yield bonds & -26.4 & Global bonds & 27.7 \\
\hline Municipal bonds & -7.4 & Long-term U.S. government bonds \\
\hline
\end{tabular}

Source: CNNMoney.com (2009).

The consequences and impact of a global financial crisis like FC08 were deleveraging and disinvestment with falling consumption and exports. The plummeting U.S. home values with the free-fall of the stock markets globally and wealth destruction produced a global recession. The falling confidence in the capital markets led to higher capital cost requirements when investors shift out of equity assets into safer assets like government bonds and foreign assets. Economic growth decelerated rapidly while food and energy prices accelerated, especially in emerging and developing countries where food is a larger proportion of their consumption basket. The global economic output fell from 3 per cent in 2008 to -0.6 per cent in 2009 (International Monetary Fund, 2010b) and unemployment remained at prolonged high levels, in the U.S. being consistently above 7.5 per cent.

The FC08 has decreased growth globally and impaired capital flows to emerging and developing countries. Economic dynamics are also changing where emerging and developing economics are leading growth rather than advanced economies and world consumption demand are being refocused from advanced to developing countries. The crisis has increased the government deficit spending on advanced countries with little room for manoeuvre given the already high government debt and the weak growth projections (International Monetary Fund, 2012). The FC08 exposed the weaknesses of global financial institutions in today's dynamic environment and the need for financial sector reforms and regulations to respond quickly and 
for global banking collaboration. Public confidence in the financial markets has to be rebuilt for investment and economic growth to resume. Emerging and developing economies are dependent on the economic recovery of developed countries for better growth prospects. However, it has been argued that global growth and recovery will have to come from and be sustained by Asian countries and China (Blanchard, 2009). This may well be as the International Monetary Fund (IMF) has projected that the newly industrialized Asian countries will be growing faster than advanced countries, the United States, and the euro area countries in 2017.

\section{Recovery from the Global Systemic Crisis}

Stiglitz (1999) presciently argued that recovery cannot be hailed a success if the exchange rate is stable, if a country falls into a deep and prolonged recession and until unemployment has returned to normal levels and growth has resumed. By this definition, the U.S. has not recovered with unemployment in 2013 at 7.7\%. The average real GDP growth rate from 2010-2015 is an anemic $2.1 \%$ (in 2009, real GDP growth was $-2.8 \%$ ).

The global systemic crisis did not stabilize and market confidence did not return until 2009. The immediate response of the Federal Reserve (Fed) was to implement emergency mechanisms to revive the credit market and alleviate the liquidity crunch. The Fed provided credit guarantees and an insurance of senior interbank debt and unlimited deposit insurance for non-interest bearing deposits, raised personal deposit insurance ceiling from $\$ 100,000$ to $\$ 250,000$, extended open discount windows cutting the fed funds rate by 300 basis points, and injected $\$ 250$ billion liquidity into the U.S. banks. To instil confidence some distressed financial institutions (Bear Sterns, AIG, Fannie Mae and Freddie Mac) were bailed out but not the Lehman Brothers whose bankruptcy was attributed to triggering the global systemic crisis and the subsequent global stock markets crash. The U.S. Troubled Assets Relief Plan (TARP) was authorized to inject $\$ 700$ billion to remove distressed mortgage-backed securities from the banks' balance sheets and to jumpstart bank lending when the credit markets froze up due to the Lehman Brothers' collapse. The UK and EU central banks responded similarly by injecting massive liquidity into their banks, cutting interest rates, purchasing toxic assets, and providing guarantees.

The subsequent contraction in capital flows and reversal in extreme risk aversion from deleveraging and disinvestment has slowed the recovery globally. Most of the Asian countries recovered faster in 2008 probably because of their less sophisticated financial markets and, therefore, less exposure to the toxic assets than other countries which took place mostly in 2009. 
The accommodative macro-policies undertaken by advanced countries like the U.S. and those in the EU have stabilized the global economy. However, neither the U.S. nor the Euro zone countries have fully recovered from the FC08 seven years later, particularly with the EU going through two episodes of the euro crises. The sluggish recovery of the above named countries meant that export dependent emerging countries also experienced lower growth (International Monetary Fund, 2012). The future recovery is focused on the EU and their ability to resolve the fiscal debt problems of a number of their members: Greece, Spain, Italy, and Ireland.

A comparison of the global economic recovery statistics from 2007-2017 is shown in Table 2. The advanced economies, especially the U.S. and the EU countries trail behind the advanced and emerging and developing economies in world output. Emerging and developing

Table 2. Global economic statistics 2007-2017 (percentage change year to year)

\begin{tabular}{|c|c|c|c|c|c|c|c|}
\hline & 2007 & 2008 & 2009 & 2010 & 2011 & $2016^{* *}$ & $2017^{* *}$ \\
\hline \multicolumn{8}{|c|}{ Real growth of GDP } \\
\hline World & $\mathrm{n} / \mathrm{a}$ & 3.0 & -0.6 & 5.3 & 3.9 & 3.4 & 3.6 \\
\hline Advanced economies & 2.7 & 0.0 & -3.6 & 3.2 & 1.6 & 2.1 & 2.1 \\
\hline The United States & 1.9 & -0.3 & -3.5 & 3.0 & 1.7 & 2.6 & 2.6 \\
\hline Euro zone & 3.0 & 0.4 & -4.3 & 1.9 & 1.4 & 1.7 & 1.7 \\
\hline Other advanced economies & 2.2 & -0.4 & -4.0 & 3.0 & 1.4 & 2.4 & 2.8 \\
\hline Newly industrialized Asian economies* & 5.9 & 1.8 & -0.7 & 8.5 & 4.0 & 4.2 & 4.3 \\
\hline Emerging and Developing Economies & $\mathrm{n} / \mathrm{a}$ & 6.1 & 2.4 & 7.5 & 6.2 & 4.3 & 4.7 \\
\hline Central and Eastern Europe & 5.4 & 3.2 & -3.6 & 4.5 & 5.3 & 3.1 & 3.4 \\
\hline Emerging and developing Asia & 11.4 & 7.8 & 7.1 & 9.7 & 7.8 & 6.3 & 6.2 \\
\hline Middle East, North Africa, Afghanistan, and Pakistan & 5.6 & 4.7 & 2.7 & 4.9 & 3.5 & 3.6 & 3.6 \\
\hline \multicolumn{8}{|c|}{ Real Total Domestic Demand } \\
\hline Advanced economics & 2.4 & -0.4 & -4.0 & 3.1 & 1.2 & 1.8 & 2.6 \\
\hline Other advanced economies & 4.9 & 1.5 & -2.8 & 5.6 & 2.7 & 3.2 & 3.4 \\
\hline Newly industrialized Asian economies* & 4.5 & 1.4 & -3.0 & 7.4 & 2.4 & 3.4 & 4.1 \\
\hline World trade volume & $\mathrm{n} / \mathrm{a}$ & 2.8 & -10.7 & 12.9 & 5.8 & 3.4 & 4.1 \\
\hline \multicolumn{8}{|c|}{ Imports } \\
\hline Advanced economies & 5.2 & 0.5 & -12.2 & 11.5 & 4.3 & 3.7 & 4.1 \\
\hline Emerging and developing economies & 14.3 & 8.3 & -9.3 & 16.0 & 9.4 & 3.4 & 4.3 \\
\hline \multicolumn{8}{|c|}{ Exports } \\
\hline Advanced economies & 6.8 & 1.9 & -11.5 & 12.2 & 5.3 & 3.4 & $\mathrm{n} / \mathrm{a}$ \\
\hline Emerging and developing economies & 9.5 & 4.3 & -8.4 & 15.0 & 6.4 & 6.5 & $\mathrm{n} / \mathrm{a}$ \\
\hline \multicolumn{8}{|c|}{ Consumer Prices } \\
\hline Advanced economies & 2.2 & 3.4 & 0.1 & 1.5 & 2.7 & 1.1 & 1.7 \\
\hline Emerging and developing economies & 6.5 & 9.2 & 5.2 & 6.1 & 7.1 & 5.6 & 5.9 \\
\hline
\end{tabular}

* Data from 2012.

** Projected.

Source: IMF World Economic Outlook (2010, 2012, 2016). 
economies recovered much faster and by 2010 their real GDP growth was $7.5 \%$ with the emerging and developing Asia leading the charge with 9.7\%. Recovery dipped down in 2011 due to the continuing Euro zone crisis. The Euro zone is projected to have a real GDP growth rate of only $1.7 \%$ in 2016 and 2017 . World Trade Volume was significantly disrupted as a result of the FC08 crisis, with exports of $-11.5 \%$ in Advanced Economies in 2009, recovering in 2010 and projected to be only $3.4 \%$ in 2016 , while the emerging and developing countries recovered quickly but less than before the crisis. The contraction in trade has produced rising protectionism and currency wars (Wall Street Journal, 2013a; 2013b). The consumer prices of Advanced Economies are projected to be only 1.1 and 1.7\% in 2016 and 2017, respectively, showing anemic recovery from the prolonged recession. Two years after the crisis, the emerging economies experienced the highest inflation of $7.1 \%$ in 2011 , but still below the pre-crisis level.

Looking ahead, the forecast for a healthy and robust recovery does not seem promising. World real GDP for the advanced economies of the world is projected to grow at only $3.6 \%$, with the highest projected growth coming from the emerging and developing Asian countries at $6.2 \%$ in 2017 , both of which are at and below the pre-crisis level. The FC08 crisis has a longer sustained impact on global economies to recover and the Asian economies will be leading the advanced countries in the recovery effort. The U.S. Stock market in 2016 has also recovered to its pre-crisis level and beyond. However, the recovery is not due to improved economic fundamentals. Rather the recovery is due to the Fed injecting a massive liquidity of $\$ 3.5$ trillion through its three Quantitative Easing bond buybacks into the economy which is buoying up the stock market. China was insulated from the financial crisis but as an emerging export dependent economy it experienced the post crisis effect from the slowing global growth. The initial Chinese recovery was similarly buoyed up by substantial injections of $\$ 2.8$ trillion into infrastructure investments and development in 2009-2010 financed by state-owned banks, creating a potential banking debt crisis by 2016 (Bloomberg, 2011; Wall Street Journal 2013c). The severity and widespread impact of the FC08 crises is thus far reaching and also far into the future.

\section{Methodology and data}

It is usual to assume that national or regional capital markets volatility can be described by the time series of stock indexes. Therefore, we can describe the conditions of the stock market recovery in our study as represented by the main stock indexes. Statistically significant changes of returns, measured by daily logarithmic rates of return, and risk, measured by standard deviation or variance of logarithmic rates of return let us distinguish between bull and bear markets. 
The analysis is provided for 30 stock indexes representing national capital markets from Australia, North and South America, and Europe (Table 3), together with the index S\&P Europe 350, representing the aggregated European market, in which the portfolio is created from 350 leading blue-chip companies drawn from 17 developed European markets. ${ }^{1}$

In order to distinguish advanced economies from emerging and developing countries we use the ranking of countries made according to GDP (PPP) per capita in 2015 as a criterion of the state classification, assuming that 35 -th position is the threshold dividing states into two classes. In such a way we create two groups of countries containing 15 objects each (Table 3 ). It is worth mentioning that the ranking presented in Table 3 differs from the IMF classification. ${ }^{2}$

Table 3. Selected countries due to the GDP (PPP) per capita in the year 2015 ranking

\begin{tabular}{|c|c|c|c|c|c|}
\hline \multicolumn{3}{|c|}{ Advanced economies } & \multicolumn{3}{|c|}{ Emerging and developing economies } \\
\hline country & $\begin{array}{c}\text { no. in the GDP } \\
\text { per capita ranking }\end{array}$ & $\begin{array}{l}\text { stock index } \\
\text { abbreviation }\end{array}$ & country & $\begin{array}{c}\text { no. in the GDP } \\
\text { per capita ranking }\end{array}$ & $\begin{array}{c}\text { stock index } \\
\text { abbreviation }\end{array}$ \\
\hline Singapore & 3 & STI & Czech Rep. & 37 & PX \\
\hline Switzerland & 9 & SMI & Slovakia & 40 & SAX \\
\hline Hong Kong & 10 & HIS & Greece & 45 & ATHEX \\
\hline The USA & 11 & NASDAQ 100 & Poland & 47 & WIG 20 \\
\hline Holland & 15 & AEX & Hungary & 48 & BUX \\
\hline Taiwan & 16 & TAIEX & Malaysia & 49 & KLCI \\
\hline Australia & 17 & AOI & Mexico & $51+$ & IPC \\
\hline Sweden & 18 & OMX & Brazil & $51+$ & IBVSP \\
\hline Germany & 20 & DAX & Chile & $51+$ & IPSA \\
\hline Canada & 21 & S\&P/TSX & The Philippines & $51+$ & PSEI \\
\hline France & 25 & CAC 40 & Indonesia & $51+$ & JCI \\
\hline The UK & 27 & FTSE 100 & China & $51+$ & SSE \\
\hline Japan & 29 & NIKKEI 225 & Shanghai & $51+$ & $\mathrm{CNY}$ \\
\hline South Korea & 30 & KOSPI & Turkey & $51+$ & XU 100 \\
\hline Spain & 33 & IBEX & Croatia & $51+$ & CROBEX \\
\hline
\end{tabular}

Note: The position of countries with lower values of GDP per capita than 51-st position in the GDP world ranking are marked by $51+$.

Source: own elaboration on the basis of http://statisticstimes.com/economy/projected-world-gdp-capita-ranking.php (14.06.2016).

In our investigation we have examined the performance of capital markets in two samples: the pre-crisis period (denoted as P1) as the one before the Lehman Brothers Holdings Inc. bankruptcy from January, 1, 2005 up to September 15, 2008, and the second sample (P2) from

\footnotetext{
1 To be included in the S\&P Europe 350 index, a company must meet certain criteria, including: market capitalization (size must be in the top 95th percentile), public float (who holds the stock), liquidity, domicile, type of securities (stocks and preferred stocks are generally eligible), and sector classification.

${ }^{2}$ It is especially visible for the European states because in our opinion there is quite a big diversity among the euro area countries therefore they cannot be considered as a homogenous group as it is done in the IMF classification.
} 
September 16, 2008 to May, 31, 2012. We constructed both samples to be equal-length subperiods. The list of considered 31 stock indexes is presented in Table 4 together with information about data sources and the number of observations in both of the considered periods.

Table 4. Test statistics for the normality of logarithmic rates of return

\begin{tabular}{|c|c|c|c|c|c|c|c|c|}
\hline \multirow{3}{*}{ Continent } & \multirow{3}{*}{ Country } & \multirow{3}{*}{$\begin{array}{c}\text { Sources } \\
\text { of data }\end{array}$} & \multirow{2}{*}{\multicolumn{2}{|c|}{$\begin{array}{c}\text { Number of } \\
\text { observations }\end{array}$}} & \multicolumn{4}{|c|}{ Values of test statistics } \\
\hline & & & & & \multicolumn{2}{|c|}{ Shapiro-Wilk } & \multicolumn{2}{|c|}{ Jarque-Bera } \\
\hline & & & $\mathrm{P} 1$ & $\mathrm{P} 2$ & $\mathrm{P} 1$ & $\mathrm{P} 2$ & $\mathrm{P} 1$ & $\mathrm{P} 2$ \\
\hline Australia & Australia & A & 938 & 939 & 0.950 & 0.957 & 947.1 & 585.2 \\
\hline \multirow{3}{*}{$\begin{array}{l}\text { North } \\
\text { America }\end{array}$} & Mexico & A & 933 & 932 & 0.974 & 0.898 & 216.7 & $1,810.4$ \\
\hline & Canada & A & 930 & 931 & 0.967 & 0.898 & 209.7 & $1,903.2$ \\
\hline & The USA & $\mathrm{B}$ & 930 & 935 & 0.981 & 0.956 & 28.3 & 49.1 \\
\hline \multirow{2}{*}{$\begin{array}{l}\text { South } \\
\text { America }\end{array}$} & Brazil & A & 964 & 968 & 0.928 & 0.973 & $1,469.1$ & 256.2 \\
\hline & Chile & $\mathrm{C}$ & 920 & 928 & 0.957 & 0.948 & 540.2 & 356.2 \\
\hline \multirow{10}{*}{ Asia } & South Korea & $\mathrm{B}$ & 915 & 928 & 0.973 & 0.909 & 189.7 & $4,298.0$ \\
\hline & Hong Kong & $\mathrm{A}$ & 925 & 933 & 0.923 & 0.915 & $1,446.4$ & $2,298.0$ \\
\hline & Malaysia & $\mathrm{A}$ & 917 & 916 & 0.872 & 0.473 & $16,497.1$ & $318,846.0$ \\
\hline & Japan & $\mathrm{B}$ & 877 & 882 & 0.910 & 0.977 & 123.9 & $2,722.3$ \\
\hline & Philippines & $\mathrm{B}$ & 910 & 909 & 0.958 & 0.913 & 762.5 & $4,348.8$ \\
\hline & Indonesia & $\mathrm{B}$ & 902 & 904 & 0.955 & 0.955 & 53.8 & 54.2 \\
\hline & China & A & 937 & 942 & 0.951 & 0.956 & 394.1 & 405.4 \\
\hline & Singapore & $\mathrm{B}$ & 927 & 928 & 0.954 & 0.929 & 417.9 & 992.8 \\
\hline & Taiwan & $\mathrm{A}$ & 908 & 917 & 0.956 & 0.956 & 330.9 & 255.6 \\
\hline & Shanghai & A & 937 & 942 & 0.951 & 0.956 & 394.1 & 405.4 \\
\hline \multirow{15}{*}{ Europe } & Switzerland & $\mathrm{A}$ & 930 & 952 & 0.967 & 0.902 & 358.4 & $2,243.3$ \\
\hline & The UK & A & 934 & 938 & 0.959 & 0.918 & 1915.4 & $5,926.4$ \\
\hline & Sweden & $\mathrm{D}$ & 925 & 937 & 0.972 & 0.952 & 132.6 & 450.2 \\
\hline & France & A & 946 & 953 & 0.966 & 0.937 & 503.5 & 873.5 \\
\hline & Germany & $\mathrm{B}$ & 943 & 947 & 0.960 & 0.938 & 784.7 & 881.1 \\
\hline & Greece & $\mathrm{B}$ & 923 & 928 & 0.954 & 0.977 & 624.9 & 249.9 \\
\hline & Turkey & $\mathrm{B}$ & 936 & 931 & 0.990 & 0.950 & 82.7 & 715.7 \\
\hline & Spain & B & 943 & 947 & 0.942 & 0.950 & 1337.7 & 999.0 \\
\hline & Holland & B & 946 & 952 & 0.958 & 0.913 & 622.6 & $1,378.8$ \\
\hline & Poland & $E$ & 928 & 934 & 0.988 & 0.961 & 68.1 & 287.2 \\
\hline & Hungary & $\mathrm{F}$ & 929 & 933 & 0.994 & 0.944 & 25.5 & 936.4 \\
\hline & Czech Rep. & $\mathrm{B}$ & 934 & 933 & 0.944 & 0.875 & 880.1 & $4,485.6$ \\
\hline & Croatia & G & 918 & 930 & 0.952 & 0.955 & 654.1 & 55.8 \\
\hline & Slovakia & $\mathrm{B}$ & 895 & 924 & 0.883 & 0.720 & 838.3 & $25,572.9$ \\
\hline & Europe & $\mathrm{B}$ & 890 & 935 & 0.972 & 0.941 & 207.5 & 639.6 \\
\hline
\end{tabular}

Note: in our investigation we classified Turkey as a European state since it has been accessing to the European Union.

Source: own calculations on the basis of the following data sources: A - finance.yahoo.com, B - stooq.pl, C - money. pl, D - etf.com.pl, E - gpwinfostrefa.pl, F - gielda.onet.pl, G - finnzen.net/index/historical.

Our analysis is provided for daily logarithmic rates of return. To recognize the market trend we verified the following hypothesis. 


$$
\mathrm{H}_{0}: \mu=\mu_{0}
$$

with the test statistics:

$$
u=\frac{\bar{y}-\mu_{0}}{S} \sqrt{n}
$$

where: $\mu$ - is the expected return, and $\mu_{0}$-a benchmark, $\bar{y}$-average logarithmic rates of return $y_{i}$ obtained in the sample in the certain period of time, $S$ - standard deviation in the sample, $n-$ number of observations in the time series. In our study we applied three different benchmarks: zero to check if returns are profits or losses, returns from the U.S. market represented by the index S\&P500 (S\&P) and European market represented by EURO STOXX 50 (EURO). These tests are provided for all investigated stock indexes and both periods separately.

The main aim of our investigation is to test if there are significant changes in the diverse capital markets by verifying the following hypotheses:

$$
\begin{aligned}
& H_{0}: \mu_{1}=\mu_{2} \\
& H_{0}: \sigma_{1}^{2}=\sigma_{2}^{2}
\end{aligned}
$$

where: $\mu_{1}, \mu_{2}, \sigma_{1}^{2}, \sigma_{2}^{2}$ - are the expected returns, and variances of returns in the two periods P1 and $\mathrm{P} 2$, respectively.

The parametric tests commonly used to verify null hypotheses (3) and (4) require fulfilling the assumption about the normality of the logarithmic rates of return in the analysed time series. To test daily returns for normality we used the Shapiro-Wilk and Jarque-Bera tests. The obtained results (Table 4) prove that none of the returns is normally distributed. In such a case the application of parametric tests is not recommended. Therefore, we apply the nonparametric tests of Mann-Whitney (WM) and Levene (L). The former will be used to check the changes in returns and the latter to check the risk. The test statistics in the Mann-Whitney test is as follows (Mann-Whitney 1947):

$$
u=\frac{U-0.5 \times n_{1} n_{2}}{\sqrt{\frac{1}{12} n_{1} n_{2}\left(n_{1}+n_{2}+1\right)}} ; \quad U=n_{1} n_{2}+\frac{n_{1}\left(n_{1}+1\right)}{2}-W ; \quad W=\sum_{j=1}^{n_{1}} R_{j}
$$

where: $n_{1}, n_{2}$ - number of observations in both series, $R_{j}-$ ranks in the sample when all $n=n_{1}+$ $n_{2}$ are ranked together, $u$ - test statistic (normally distributed). 
The test statistic for the Levene test is as follows (Levene, 1960):

$$
\begin{gathered}
L=\frac{n-k}{k-1} \times \frac{\sum_{i=1}^{k} n_{i}\left(\bar{z}_{i}-\bar{z}\right)^{2}}{\sum_{i=1}^{k} \sum_{j=1}^{n_{i}}\left(z_{j i}-\bar{z}_{i}\right)^{2}} ; \quad z_{j i}=\left|y_{i j}-\bar{y}_{i}\right| ; \quad \bar{y}_{i}=\frac{1}{n_{i}} \sum_{j=1}^{n_{i}} y_{i j} ; \\
\bar{z}_{i}=\frac{1}{n_{i}} \sum_{j=1}^{n_{i}} y z_{i j} ; \quad \bar{z}=\frac{1}{n} \sum_{i=1}^{k} z_{i} n_{i}
\end{gathered}
$$

where: $y_{i j}$-rates of return in the $j$-th moment that belong to the $i$-th period.

The verification of above described hypotheses let us identify the states of the capital markets in the considered countries. To answer the question if the certain market has been already recovered from the worldwide financial crises or not we analysed the sequences of the different trends distinguished for this market and assumed that the market recovers after the crisis when after the bear market the bull market appears in the investigated period.

\section{Results}

In Table 5 the descriptive statistics of the analysed time series of returns such as expected returns, standard deviation, asymmetry and kurtosis for both periods are shown. As can be seen, in the pre-crisis period the returns for all indexes are positive while in the second sample some are positive and some are negative. The risk and uncertainty are observable with higher standard deviations in the period P2 than in P1. The highest coefficients of variation which show the extent risk in relation to the expected return are observed for Hong Kong, Canada, the UK and Germany in the period P2 together with Japan and Taiwan in the period P1. In general the values of these coefficients are bigger in the first period in Mexico, the USA, Malaysia, the Philippines, Indonesia, Taiwan, France, Greece Turkey, Spain, Holland and Slovakia i.e. variability of returns was bigger in these countries before the Lehman Brother bankruptcy.

Asymmetry is mostly negative in both of the considered periods, and kurtosis shows that all series are leptokurtic (Table 5). Leptokurtic distributions have higher peaks around the mean compared to normal distributions, leading to thick tails on either side. These peaks are the results from the data being highly concentrated around the mean, due to lower variations within the observations. 
Table 5. Basic characteristics of the logarithmic rates of return

\begin{tabular}{|c|c|c|c|c|c|c|c|c|c|}
\hline \multirow{2}{*}{ State } & \multirow{2}{*}{ Stock index } & \multicolumn{2}{|c|}{ Returns $y$} & \multicolumn{2}{|c|}{ Standard deviation $\mathrm{S}$} & \multicolumn{2}{|c|}{ Asymmetry } & \multicolumn{2}{|c|}{ Kurtosis } \\
\hline & & $\mathrm{P} 1$ & $\mathrm{P} 2$ & $\mathrm{P} 1$ & $\mathrm{P} 2$ & $\mathrm{P} 1$ & $\mathrm{P} 2$ & $\mathrm{P} 1$ & $\mathrm{P} 2$ \\
\hline Australia & AOI & 0.0002 & -0.0002 & 0.0103 & 0.0135 & -0.4590 & -0.4923 & 4.87 & 3.77 \\
\hline Mexico & IPC & 0.0007 & 0.0004 & 0.0132 & 0.0160 & -0.1138 & 0.3711 & 2.37 & 6.83 \\
\hline Canada & S\&P/TSX & 0.0004 & -0.0001 & 0.0093 & 0.0163 & -0.6513 & -0.5559 & 1.95 & 6.96 \\
\hline The USA & NASDAQ100 & 0.0001 & 0.0004 & 0.0116 & 0.0181 & -0.1000 & -0.1600 & 1.09 & 6.73 \\
\hline Brazil & IBVSP & 0.0003 & 0.0005 & 0.0214 & 0.0163 & -0.0968 & 0.0876 & 6.08 & 2.53 \\
\hline Chile & IPSA & 0.0005 & 0.0005 & 0.0104 & 0.0414 & -0.4234 & -0.0027 & 3.68 & 77.64 \\
\hline South Korea & KOSPI & 0.0006 & 0.0003 & 0.0130 & 0.0170 & -0.4399 & -0.5669 & 2.07 & 7.42 \\
\hline Hong Kong & HSI & 0.0003 & 0.0000 & 0.0145 & 0.0200 & -0.1247 & 0.0150 & 6.16 & 7.73 \\
\hline Malaysia & KLCI & 0.0002 & 0.0005 & 0.0088 & 0.0153 & -1.9958 & 0.2080 & 20.51 & 91.91 \\
\hline Japan & Nikkei 225 & 0.0000 & -0.0002 & 0.0056 & 0.0085 & -0.4129 & -0.4663 & 1.66 & 8.61 \\
\hline The Philippines & PSEI & 0.0004 & 0.0008 & 0.0139 & 0.0145 & -0.0247 & -0.9807 & 4.46 & 10.50 \\
\hline Indonesia & JCI & 0.0007 & 0.0009 & 0.0146 & 0.0165 & -0.7009 & -0.0658 & 4.43 & 7.57 \\
\hline China & SSE & 0.0005 & 0.0002 & 0.0194 & 0.0163 & -0.4693 & -0.0973 & 3.06 & 3.23 \\
\hline Singapore & STI & 0.0002 & 0.0001 & 0.0113 & 0.0147 & -0.3234 & -0.11710 & 3.25 & 5.10 \\
\hline Taiwan & TAIEX & 0.0002 & 0.0001 & 0.0113 & 0.0147 & -0.3234 & -0.1171 & 3.25 & 5.10 \\
\hline Shanghai & $\mathrm{CNY}$ & 0.0000 & 0.0002 & 0.0127 & 0.0147 & -0.5378 & -0.2565 & 2.78 & 2.56 \\
\hline Switzerland & SMI & 0.0005 & 0.0002 & 0.0194 & 0.0163 & -0.4693 & -0.0973 & 3.06 & 3.23 \\
\hline The UK & FTSE100 & 0.0002 & -0.0002 & 0.0097 & 0.0142 & -0.3537 & 0.1754 & 2.98 & 7.56 \\
\hline Sweden & OMX & 0.0001 & 0.0000 & 0.0101 & 0.0160 & -0.2356 & -0.0077 & 3.10 & 6.27 \\
\hline France & CAC40 & 0.0001 & 0.0002 & 0.0126 & 0.0187 & -0.2298 & 0.1468 & 1.81 & 3.40 \\
\hline Germany & DAX & 0.0001 & -0.0003 & 0.0108 & 0.0191 & -0.0405 & 0.0173 & 3.51 & 4.71 \\
\hline Europe & $\begin{array}{l}\text { S\&P } \\
\text { Europe } 350\end{array}$ & 0.0004 & 0.0000 & 0.0105 & 0.0183 & -0.5684 & 0.1953 & 4.35 & 4.74 \\
\hline Greece & ATHEX & 0.0001 & 0.0003 & 0.0111 & 0.0232 & -0.4271 & -0.0175 & 2.23 & 4.07 \\
\hline Turkey & XU100 & 0.0004 & 0.00048 & 0.0182 & 0.0187 & -0.3100 & -0.0480 & 1.331 & 4.324 \\
\hline Spain & IBEX & 0.0002 & -0.0016 & 0.0124 & 0.0238 & -0.1254 & 0.3259 & 4.05 & 2.48 \\
\hline Holland & AEX & 0.0004 & 0.0005 & 0.0182 & 0.0187 & -0.3100 & -0.0480 & 1.33 & 4.32 \\
\hline Poland & WIG20 & 0.0002 & -0.0006 & 0.0109 & 0.0196 & -0.5124 & 0.3035 & 5.78 & 5.03 \\
\hline Hungary & BUX & 0.0001 & -0.0003 & 0.0102 & 0.0184 & -0.3540 & -0.1070 & 3.94 & 5.93 \\
\hline Czech Rep. & $\mathrm{PX}$ & 0.0002 & -0.0001 & 0.0148 & 0.0186 & -0.2778 & -0.2587 & 1.22 & 2.74 \\
\hline Croatia & CROBEX & 0.0003 & -0.0002 & 0.0142 & 0.0220 & -0.1783 & -0.0219 & 0.74 & 4.94 \\
\hline Slovakia & SAX & 0.0002 & -0.0004 & 0.0127 & 0.0205 & -0.2910 & -0.4895 & 4.72 & 10.70 \\
\hline
\end{tabular}

Source: own calculations.

Table 6 contains the test statistics provided for null hypotheses (1), (3) and (4) with bold letters denoting a rejection of the null hypothesis at the significance level of $\alpha=0.05$. If the expected returns are significantly greater than zero, a bull market exists and if they are significantly less than zero, a bear market is recognized. In fact, only indexes in Mexico and Croatia are significantly positive in the period P1, reflecting the bull market, while in the period P2 significantly negative returns are observed for the index S\&P Europe 350, Greece and Slovakia. Such results seem to be caused by the fact that a decreasing trend was observed 
in the majority of the stock markets about a year before the Lehman Brothers bankruptcy on September 15, 2008 (see Figure 1). Therefore, it is possible to find out time spans when the stock indexes were increasing and decreasing in both periods i.e. before and after the bankruptcy.

It can also be observed that returns from the majority of indexes are similar to both the benchmarks - indexes of S\&P 500 and the EURO STOXX 50. The significant differences are observed only for the Greece market in the period P2 when S\&P 500 is compared, for the Croatian index in the period P1 for both benchmarks, for the USA, the Philippines and Indonesia markets in the period P2 when the EURO STOXX 50 is considered as a benchmark.

The Mann-Whitney test shows the significant differences between returns in both P1 and P2 periods for all markets, except Canada, Hong Kong, the Philippines, China, Shanghai, France, Germany, Turkey, Holland, Hungary, and the stock index S\&P Europe 350. However, for all these markets (except Turkey and the Philippines) we can observe significant differences of risk as measured by the Levene test. Other investigated stock indexes show significant differences in risk, except for Mexico, Malaysia, and Taiwan, where changes in risk in both periods are not significant.

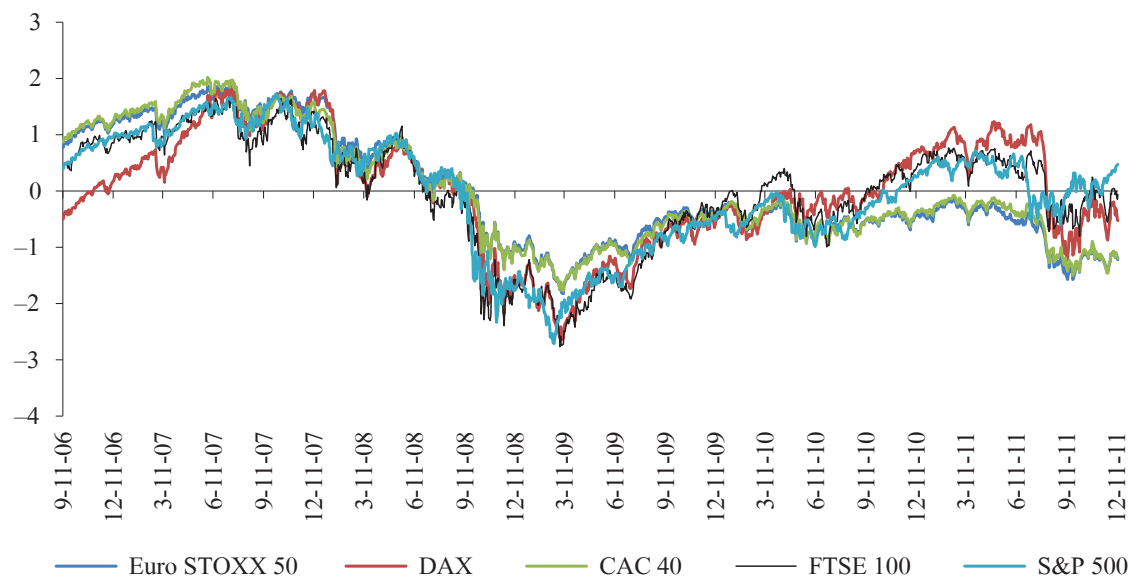

Figure 1. Standardized charts of quotations of the major stock indexes Source: own elaboration.

In other words, we can claim that the financial crisis appeared in considered states since both periods are characterized by a different situation in all of the investigated countries, except Turkey where the stock index XU100 does not significantly differ in both of the distinguished periods. However, we can conclude that the division for period P1 and P2 is not the same as for the bull and bear markets for the majority of countries. Therefore, we can ask the question 
when did the bull market end and then when did the crisis end in each of the analysed states. To decide about "real" tendencies in domestic or regional markets we provided an analysis of stock indexes plots, and verifying hypothesis (1) for $\mu_{0}=0$. This investigation let us determine the bull, bear and stagnation periods. We can assume that the crisis in a particular country was over when the bear market (that usually ended in 2009) a long-lasting bull market appears. If there are "ups and downs" or stagnation, we treat such a market as one which is "still fighting with the crisis".

Table 6. Test statistics evaluated to verify hypotheses (1), (3) ad (4)

\begin{tabular}{|c|c|c|c|c|c|c|c|c|c|}
\hline \multirow[b]{3}{*}{ State } & \multirow[b]{3}{*}{ Index } & \multicolumn{6}{|c|}{ Test statistics (2) $u$ evaluated for $\mathrm{H}_{0}(1)$} & \multicolumn{2}{|c|}{ Test statistics } \\
\hline & & \multicolumn{2}{|c|}{$\mu_{0}=0$} & \multicolumn{2}{|c|}{$\mu_{0}=\mathrm{S} \& \mathrm{P}$} & \multicolumn{2}{|c|}{$\mu_{0}=$ EURO } & \multirow{2}{*}{$\begin{array}{l}\text { (5) } u \\
\text { (3) } H_{0}\end{array}$} & \multirow{2}{*}{$\begin{array}{c}\text { (6) } L \\
\text { (4) } H_{0}\end{array}$} \\
\hline & & P1 & $\mathrm{P} 2$ & P1 & $\mathrm{P} 2$ & P1 & $\mathrm{P} 2$ & & \\
\hline Australia & AOI & 0.635 & -0.398 & 0.167 & -0.564 & 0.291 & -0.258 & 37.661 & 36.629 \\
\hline Mexico & IPC & 1.667 & 0.801 & 1.283 & 0.471 & 1.092 & 1.080 & -1.645 & 1.538 \\
\hline Canada & S\&P/TSX & 1.177 & -0.126 & 0.735 & -0.212 & 0.553 & 0.429 & -0.639 & 65.537 \\
\hline The USA & NASDAQ100 & 0.156 & 1.237 & 0.086 & 1.167 & -0.079 & 2.065 & 24.054 & 193.040 \\
\hline Brazil & IBVSP & 0.427 & 1.032 & 0.086 & 0.881 & 0.340 & 1.250 & 1.645 & 32.534 \\
\hline Chile & IPSA & 1.440 & 0.034 & 1.065 & 0.002 & 1.612 & 0.038 & -1.960 & 858.144 \\
\hline South Korea & KOSPI & 1.284 & 0.548 & 1.182 & 0.368 & 1.038 & 1.294 & 1.645 & 662.282 \\
\hline Hong Kong & HSI & 0.694 & 0.029 & 0.500 & -0.072 & 0.376 & 0.463 & -0.856 & 45.674 \\
\hline Malaysia & KLCI & 0.539 & 0.895 & 0.265 & 0.515 & -0.041 & 1.143 & -7.932 & 1.739 \\
\hline Japan & Nikkei 225 & 0.153 & -0.529 & 0.012 & -0.662 & -0.108 & 0.140 & -8.272 & 36.688 \\
\hline The Philippines & PSEI & 0.860 & 1.595 & 0.765 & 1.386 & 0.544 & 2.714 & 0.621 & 0.006 \\
\hline Indonesia & JCI & 1.347 & 1.509 & 1.255 & 1.417 & 1.039 & 2.602 & 24.500 & 133.230 \\
\hline China & SSE & 0.837 & 0.355 & 0.769 & 0.200 & 0.608 & 1.352 & -1.421 & 13.140 \\
\hline Singapore & STI & 0.511 & 0.855 & 0.703 & -0.069 & 0.896 & 0.805 & 24.848 & 139.301 \\
\hline Taiwan & TAIEX & 0.039 & 0.305 & 0.449 & 0.401 & -0.078 & 0.154 & 24.617 & 1.397 \\
\hline Shanghai & CNY & 0.837 & 0.355 & 0.769 & 0.200 & 0.608 & 1.352 & -1.421 & 13.140 \\
\hline Switzerland & SMI & 0.075 & -0.388 & 0.592 & -0.391 & 0.769 & -0.239 & 1.645 & 37.131 \\
\hline The UK & FTSE100 & 0.361 & 0.045 & 0.229 & -0.048 & 0.042 & 0.921 & 36.537 & 67.077 \\
\hline Sweden & OMX & -0.113 & -0.950 & -0.114 & -0.952 & \begin{tabular}{|l|}
-1.069 \\
\end{tabular} & -0.934 & 24.938 & 393.012 \\
\hline France & CAC40 & 0.349 & -0.550 & 0.227 & -0.629 & -0.034 & 0.093 & -0.304 & 111.251 \\
\hline Germany & DAX & 1.157 & 0.008 & 0.783 & 0.052 & 0.777 & -0.052 & -0.495 & 119.376 \\
\hline Europe & S\&P Europe 350 & 0.978 & -1.925 & 0.097 & -0.034 & -0.048 & 0.081 & -0.054 & 15.329 \\
\hline Greece & ATHEX & 0.445 & -2.007 & 0.188 & -1.875 & 0.039 & -1.343 & -1.645 & 212.043 \\
\hline Turkey & XU100 & 0.673 & 0.793 & 0.535 & 0.514 & 0.430 & 1.084 & 0.253 & 1.425 \\
\hline Spain & IBEX & 0.671 & -0.966 & 0.307 & -1.168 & 0.842 & -0.871 & 25.016 & 333.001 \\
\hline Holland & AEX & 0.405 & -0.500 & 0.202 & -0.414 & 0.061 & 0.186 & -0.464 & 101.137 \\
\hline Poland & WIG20 & 0.465 & -0.211 & 0.415 & -0.377 & 0.196 & 0.672 & -8.626 & 13.824 \\
\hline Hungary & BUX & 0.660 & -0.030 & 0.046 & -0.263 & 0.807 & 0.258 & -0.201 & 56.394 \\
\hline Czech Rep. & PX & 0.533 & -0.057 & 0.428 & -0.722 & 0.183 & 0.231 & -9.672 & 50.231 \\
\hline Croatia & CROBEX & 2.140 & -1.274 & 2.019 & -1.360 & 1.726 & -0.211 & 2.714 & 19.572 \\
\hline Slovakia & SAX & 0.978 & -1.925 & 0.485 & -1.215 & 0.226 & -0.0615 & 2.055 & 15.329 \\
\hline
\end{tabular}

Source: own calculations. 
An analysis of the stock index plots and testifying the hypotheses (1) are carried out and the different trends of the stock indexes are presented in Tables 7 and 8 . In the following columns we present dates of the end of a certain tendency in the market, starting from the beginning of January 2005 till the end of March 2013. We noted an increasing trend ( $\uparrow$ ), a decreasing trend $(\downarrow)$, and a horizontal trend $(\rightarrow)$. Information in the last column informs about the situation which was observed at the end of March 2013.

As is shown in the tables, the global capital markets recovery is not homogenous, with increasing and decreasing trends in the different markets. For instance, the Australian stock index AOI was increasing till 1.11.2007, then decreasing till 6.03.2009 and increasing till 15.04.2010, the following period till 4.06.2012 was identified as a horizontal trend which was followed by a bull market till the end of March 2013. In Brazil the bull market ended on 19.05.2008 and the bear market - on 27.10.2008, then we can observe an increasing trend till 8.04.2010, horizontal till 31.03.2011 followed by an increasing tendency till the end of the analysed period.

The end of the bull market with a decreasing trend started in the majority of markets in 2007 except for Canada, Brazil, Indonesia, Singapore, Hungary and Croatia in 2008 together with Malaysia that was characterized by stagnation till August 2006, and then the bull market till January 2008, while Slovakia entered the bear market from the permanent horizontal trend. The recovery from the bear market ended at different times but for most countries in the March of 2009 although South Korea, Japan, Taiwan (among developed countries) together with Brazil, Malaysia, China, and Shanghai (among developing markets) ended the crisis by starting the bull market some months earlier. Also after changing the market trend some markets were performing better than others. Mexico, the U.S., South Korea, the Philippines, Indonesia, Germany, and Europe as an aggregate recovered very quickly, while others like Australia, Hong Kong, the UK and Sweden (among developed markets) Hungary, Chile, Croatia and Malaysia (among emerging markets) needed more time although these markets were recovering at the end of the P2 period. All countries were impacted by the FC08 crisis but some of them recovered and some after a short recovery went into a bear market again, Spain (classified as a developed market) and Greece (classified as a developing market) are two examples. Also, France, Japan, China (SSE), Croatia and Slovakia seemed not to fully recover after the FC08 since the periods of an increasing tendency (if appeared) lasted for less than 10 months. 
Table 7. Types of recovery trends: developed markets

\begin{tabular}{|l|l|c|c|c|c|c|c|}
\hline \multicolumn{1}{|c|}{ State } & \multicolumn{1}{|c|}{ Index } & \multicolumn{7}{c|}{ Following periods of different market trends } \\
\hline Australia & AOI & $1.11 .2007 \uparrow$ & $6.03 .2009 \downarrow$ & $15.04 .2010 \uparrow$ & $4.06 .2012 \rightarrow$ & 28.03 .2013 & \\
\hline Canada & S\&P/TSX & 14.09 .2008 & $6.03 .2009 \downarrow$ & $5.04 .2011 \uparrow$ & $23.02 .2012 \downarrow$ & $31.05 .2012 \rightarrow$ & \\
\hline USA & NASDAQ100 & 31.10 .2007 & $23.02 .2009 \downarrow$ & $31.05 .2012 \uparrow$ & $16.12 .2012 \rightarrow$ & $31.03 .2013 \downarrow$ & \\
\hline $\begin{array}{l}\text { South } \\
\text { Korea }\end{array}$ & KOSPI & 2.10 .2007 & $3.12 .2008 \downarrow$ & $29.03 .2013 \uparrow$ & & & \\
\hline Hong Kong & HSI & 29.10 .2007 & $9.03 .2009 \downarrow$ & $4.11 .2010 \uparrow$ & $4.10 .2011 \downarrow$ & $31.03 .2013 \uparrow$ & \\
\hline Japan & Nikkei 225 & 26.07 .2007 & $16.12 .2008 \downarrow$ & $12.11 .2012 \rightarrow$ & $31.03 .2013 \uparrow$ & & \\
\hline Singapore & STI & 15.09 .2008 & $12.03 .2009 \downarrow$ & $9.11 .2010 \uparrow$ & $28.03 .2013 \rightarrow$ & & \\
\hline Taiwan & TAIEX & $9.07 .2007 \uparrow$ & $11.04 .2008 \rightarrow$ & $4.11 .2008 \downarrow$ & $22.12 .2009 \uparrow$ & $31.03 .2013 \rightarrow$ & \\
\hline Switzerland & SMI & 1.06 .2007 & $9.03 .2009 \downarrow$ & $21.06 .2010 \uparrow$ & $28.03 .2013 \rightarrow$ & & \\
\hline The UK & FTSE100 & $31.10 .2007 \uparrow$ & $3.03 .2009 \downarrow$ & $15.04 .2010 \uparrow$ & $1.06 .2012 \rightarrow$ & $28.03 .2013 \uparrow$ & \\
\hline Sweden & OMX & 12.07 .2007 & $30.03 .2009 \downarrow$ & $11.04 .2011 \uparrow$ & $8.08 .2011 \uparrow$ & $28.03 .2013 \uparrow$ & \\
\hline France & CAC40 & 1.06 .2007 & $11.03 .2009 \downarrow$ & $10.01 .2010 \uparrow$ & $6.07 .2011 \rightarrow$ & $24.11 .2011 \downarrow$ & $28.03 .2013 \rightarrow$ \\
\hline Germany & DAX & 28.12 .2007 & $6.03 .2009 \downarrow$ & $28.03 .2013 \uparrow$ & & & \\
\hline Spain & IBEX & 19.11 .2007 & $20.03 .2009 \downarrow$ & $28.09 .2009 \uparrow$ & $31.05 .2012 \downarrow$ & $31.03 .2013 \downarrow$ & \\
\hline Holland & AEX & 9.10 .2007 & $24.02 .2009 \downarrow$ & $17.03 .2010 \uparrow$ & $31.03 .2013 \rightarrow$ & & \\
\hline Europe & S\&P Europe & 29.10 .2007 & $2.03 .2009 \downarrow$ & $28.03 .2013 \uparrow$ & & & \\
\hline
\end{tabular}

Source: own calculations.

Table 8. Types of recovery trends: emerging and developing markets

\begin{tabular}{|l|l|c|c|c|c|c|c|c|}
\hline \multicolumn{1}{|c|}{ State } & \multicolumn{1}{c|}{ Index } & \multicolumn{7}{c|}{ Following periods of different market trends } \\
\hline Mexico & IPC & $18.06 .2007 \uparrow$ & $30.05 .2008 \rightarrow$ & $9.03 .2009 \downarrow$ & $31.03 .2013 \uparrow$ & & & \\
\hline Brazil & IBVSP & $19.05 .2008 \uparrow$ & $27.10 .2008 \downarrow$ & $8.04 .2010 \uparrow$ & $31.03 .2011 \rightarrow$ & $31.03 .2013 \uparrow$ & & \\
\hline Chile & IPSA & $3.07 .2007 \uparrow$ & $26.10 .2007 \rightarrow$ & $6.03 .2009 \downarrow$ & $10.11 .2010 \uparrow$ & $4.10 .2011 \downarrow$ & $2.04 .2012 \uparrow$ & $28.03 .2013 \rightarrow$ \\
\hline Malaysia & KLCI & $22.08 .2006 \rightarrow$ & $11.01 .2008 \uparrow$ & $14.10 .2008 \downarrow$ & $8.04 .2009 \rightarrow$ & $7.07 .2011 \uparrow$ & $23.09 .2011 \downarrow$ & $29.03 .2013 \uparrow$ \\
\hline $\begin{array}{l}\text { The } \\
\text { Philippines }\end{array}$ & PSEI & 8.10 .2007 & $17.03 .2009 \downarrow$ & $27.03 .2013 \uparrow$ & & & & \\
\hline Indonesia & JCI & $14.01 .2008 \uparrow$ & $2.03 .2009 \downarrow$ & $31.03 .2013 \uparrow$ & & & & \\
\hline China & SSE & $17.12 .2005 \rightarrow$ & $15.02 .2007 \uparrow$ & $3.11 .2008 \downarrow$ & $04.08 .2009 \uparrow$ & $11.04 .2011 \rightarrow$ & $26.12 .2012 \downarrow$ & $31.03 .2013 \uparrow$ \\
\hline Shanghai & CNY & $8.10 .2007 \uparrow$ & $17.09 .2008 \downarrow$ & $20.07 .2009 \uparrow$ & $31.05 .2012 \rightarrow$ & $31.03 .2013 \uparrow$ & & \\
\hline Greece & ATHEX & $18.11 .2007 \uparrow$ & $15.03 .2009 \downarrow$ & $9.11 .2009 \uparrow$ & $31.03 .2013 \downarrow$ & & & \\
\hline Turkey & XU100 & $9.10 .2007 \uparrow$ & $11.02 .2009 \downarrow$ & $31.03 .2013 \uparrow$ & & & & \\
\hline Poland & WIG20 & $29.10 .2007 \uparrow$ & $17.02 .2009 \downarrow$ & $28.04 .2011 \uparrow$ & $31.03 .2013 \rightarrow$ & & & \\
\hline Hungary & BUX & $14.09 .2008 \uparrow$ & $4.03 .2009 \downarrow$ & $6.04 .2010 \uparrow$ & $7.04 .2011 \rightarrow$ & $23.09 .2011 \downarrow$ & $31.03 .2013 \uparrow$ & \\
\hline Czech Rep. & PX & $6.10 .2007 \uparrow$ & $17.02 .2009 \downarrow$ & $14.04 .2010 \uparrow$ & $31.03 .2013 \rightarrow$ & & & \\
\hline Croatia & CROBEX & $15.09 .2008 \uparrow$ & $9.03 .2009 \downarrow$ & $1.06 .2009 \uparrow$ & $03.07 .2009 \downarrow$ & $14.10 .2009 \uparrow$ & $18.12 .2009 \downarrow$ & $14.04 .2010 \uparrow$ \\
\hline & & & $13.11 .2010 \downarrow$ & $7.02 .2011 \uparrow$ & $28.01 .2012 \downarrow$ & $30.12 .2012 \rightarrow$ & $31.03 .2013 \uparrow$ & \\
\hline Slovakia & SAX & $17.09 .2008 \rightarrow$ & $25.05 .2010 \downarrow$ & $26.03 .2013 \rightarrow$ & & & & \\
\hline
\end{tabular}

Source: own calculations. 
Comparing those markets classified into two classes (Tables 7 to 8) we may only claim that among developing countries the recovery from the crisis required more stages since the market tendency changed after the crises more often than among the developed states. The best example is the situation observed in Croatia. However, it is difficult to find other different patterns of recovery characteristics for developed and developing economies.

\section{Conclusions}

The financial crisis had a significant impact on the stock markets in their disproportionate risks and returns. The differences in returns between both distinguished periods are not as noticeable because the Lehman Brothers Holding Inc. bankruptcy appeared when the major stock exchanges had been already declining for a year. Therefore, in further investigations the situation of individual markets was analysed.

The bull market ended in the majority of the global capital markets in the period between June and November 2007. In China (SSE) it took place in February 2007, in Germany in December 2007, in Indonesia and Malaysia in January 2008. There are eight countries where the bear market started later after April 2008: Taiwan, Mexico (where the bull market was followed by a stagnation period), Brazil, Canada, Singapore, Hungary, Croatia, and Slovakia.

After the financial crisis, most of the countries recovered from the bear market by January and March 2009. However, for Brazil, South Korea, Malaysia, Japan, China, and Taiwan the bear market ended close to the end of 2008. In Slovakia, the financial crisis seems to last longer than in other countries i.e. till the end of May 2010.

After this period, we can observe mostly dynamic and sustained recovery of the analysed stock markets. However, Croatia experienced a volatile up-and-down of a short period of an increasing trend of the market index followed by a decreasing tendency pattern. In Greece after an 8-month period of an increasing trend of the market index, a decreasing trend was observed till the end of the analysed period. Most of the stock markets experienced a sustained bull market recovery after the financial crisis ended in 2009 but stagnated by 2012. A full recovery seemed to take place in the majority of countries. Only Greece and Spain were not characterized by the long lasting (at least by 9 months) bull market period till March 2013.

It is difficult to find strong arguments that the situation in the advanced capital markets is different than in emerging and developing economies in terms of being more or less susceptible to the turbulences on the financial markets and having a better or worse ability to recover after crises. We can only notice that among developing countries the market tendency changed after 
the crises more often than among developed states, i.e. the recovery from the crisis required more stages for the emerging markets.

\section{References}

Arner, D.W. (2009). The Global Credit Crisis of 2008: Causes and Consequences. The International Lawyer, 43, 91-136.

Batram, S., and Bodnar, G. (2009). No Place to Hide: The Global Crisis in Equity Markets in 2008/2009. Journal of International Money and Finance, 28, 1246-1292.

Blanchard, O. (2009). Sustaining a Global Recovery. Finance \& Development, 46 (3), 8-12.

Bloomberg News. (2011). Crisis may Force Banks to Set up Crisis-handling Procedures. Retrieved from http:/www.bloomberg.com/news/articles/2011-02-21/china-may-forcebanks-to-set-up-procedures-for-handling-potential-crisis (12.03.2016).

Bordo, M. (2008). An Historical Perspective on the Crisis of 2007-2008. NBER Working Paper \#14569, National Bureau of Economic Research, December.

Boschi, M. (2005). International financial contagion: evidence from the Argentine crisis of 2001-2002. Applied Financial Economics, 3 (15), 153-163.

Chang, H. (2012). An International Comparison of Volatility in Stock Market Returns Prior and Post Global Financial Crisis. International Proceedings of Economics Development and Research, 29, 270-276.

CNNMoney.com (2009). 5 lessons from the crash. September 10. Retrieved from http://money. cnn.com/2009/09/09/news/economy/financial_crisis.moneymag/index.htm (16.02.2016).

Dooley, M., Hutchison, M. (2009). Transmission of the U.S. Subprime Crisis to Emerging Markets: Evidence on the Decoupling-Recoupling Hypothesis. NBER Working Paper 15120, June.

Dungey, M., Fry, R., Gonzalez- Hermosillo, B., Martin, V. (2002). International Contagion from the Russian Crisis and the LTCM near-collapse. IMF Working Paper WP/02/74, April. Retrieved from http://www.imf.org/external/pubs/ft/wp/2002/wp0274.pdf (12.03.2016).

Edwards, S., Susmel, R. (2003). Volatility Dependence and Contagion in Emerging Equity Markets. Journal of Development Economics, 66, 505-532.

Forbes, K.J., Rigobon, R. (2002). No Contagion, only Interdependence: Measuring stock Market Co-movements. Journal of Finance, 57, 2223-2261. 
Goldberg, L., Dages, B.G., Kinney, D. (2000). Foreign and Domestic Bank Participation in Emerging Markets: Lessons from Mexico and Argentina. NBER Working Paper No. 7714, May.

Goldstein, M. (1998). The Asian Financial Crisis: Causes, Cures, and Systemic Implication. Peterson Institute for International Economics, Peterson Institute Press.

International Monetary Fund (2010a). Annual Report 2010 Supporting a Balanced Global Recovery. Retrieved from https://www.imf.org/external/pubs/ft/ar/2010/eng/pdf/ar10_eng. $\operatorname{pdf}(24.06 .2016)$.

International Monetary Fund (2010b). World Economic Outlook Database.

International Monetary Fund (2012). World Economic Outlook Database.

International Monetary Fund (2016). World Economic Outlook Database.

Kenc, T., Dibooglu, S. (2010). The 2007-2009 Financial Crisis, Global Imbalances and Capital Flows: Implications for Reform. Economic Systems, 34, 2-31.

Levene, H. (1960). Robust Tests for Equality of Variances. In: I. Olkin et al. (eds.), Contribution to Probability and Statistics. Essays in Honor of Harold Hotelling (pp. 278-292). Stanford, California: Stanford University Press.

Longin, F., Solnik, B. (1995). Is Correlation in International Equity Returns Constant: 19601980. Journal of International Money and Finance, 14, 3-26.

Mann, H.B., Whitney, D.R. (1947). On a Test of Whether one of Two Random Variables is Stochastically Larger than the Other. Annals of Mathematical Statistics, 1 (18), 50-60.

Mohan, R. (2009). Global Financial Crisis: Causes, Impact, Policy Responses and Lessons. Working paper No. 407, Stanford Center for International Development, December.

Nguyen, D.K. (2005). Market Deregulations, Volatility and Spillover Effects: Experience from Emerging Stock Markets. In: S. Motamen-Samadian (ed.), Governance and Risk in Emerging and Global Markets (pp. 89-120). United Kingdom: Plagrave Macmillan.

Phylatis, K., Ravazzzolo, F. (2002). Measuring Financial and Economic Integration with Equity Prices in Emerging Markets. Journal of International Money and Finance, 21, 879-903.

Radelet, S., Sachs, J. (1999). What Have We Learned, So Far, From the Asian Financial Crisis? Retrieved from http://www.cid.harvard.edu/archive/hiid/papers/aea122.pdf.

Ramlall, I. (2009). Assessing the Impact of US Subprime Crisis on SEMDEX: In Quest for a Change in Stock Market Interdependence. International Research Journal of Finance and Economics, 30, 30-44.

Ramlall, I. (2010). Has the US Subprime Crisis Accentuated Volatility Clustering and Leverage Effects in Major International Stock Markets? International Research Journal of Finance and Economics, 39, 157-185.

Rejeb, A.B. (2013). Volatility Spillovers and Contagion: An Empirical Analysis of Structural Changes in Emerging Market Volatility. Economics Bulletin, 1 (33), 56-71. 
Sheng, H.C., Tu, A.H. (2000). A Study of Cointegration and Variance Decomposition among National Equity Indices before and during the Period of the Asian Financial Crisis. Journal of Multinational Financial Management, 10 (3), 345-365.

Sojli, E. (2007). Contagion in emerging markets: the Russian crisis. Applied Financial Economics, 17 (3), 197-213.

Stiglitz, J. (1999). Reforming the Global Economic Architecture: Lessons from Recent Crises. The Journal of Finance, 54 (4), 1508-1521.

Wall Street Journal (2013a). G-20 Brings Currency War One Step Closer. Retrieved from http://online.wsj.com/article/SB10001424127887323495104578311681662780890.html (18.02.2016).

Wall Street Journal (2013b). China Fund Warns Japan Against a "Currency War". Retrieved from http://online.wsj.com/article/SB10001424127887324034804578343913944378132. html (6.03.2016).

Wall Street Journal. (2013c). Chinese Banks feel trains after Long Credit Binge. Retrieved from http://www.wsj.com/articles/SB10001424127887323446404579010781178659564 (12.03.2016).

Wei, L. (2013). China Fund Warns Japan Against a 'Currency War'. Retrieved from http://www. wsj.com/articles/SB10001424127887324034804578343913944378132 (6.03.2016). 